\title{
Analysis of the Effect Quality Service on Telkomsel Customer Satisfaction in Karawang with the Servqual Method
}

\author{
Karya Suhada 1 \\ Study Program \\ Technical Information \\ STMIK Rosma, \\ Indonesia \\ karya@rosma.ac.id
}

\author{
Lila Setiyani $^{2}$ \\ Study Program \\ Information System \\ STMIK Rosma, \\ Indonesia \\ lila.setiyani@dosen.rosma.ac.id
}

\author{
Siti Aisyah $^{3}$ \\ Study Program \\ Information System \\ STMIK Rosma, \\ Indonesia \\ siti.aisyah@rosma.ac.id
}

\author{
Fitria Nurapriani ${ }^{4}$ \\ Information System, Faculty of \\ Engineering and Computer Science \\ Universitas Buana Perjuangan \\ Karawang, Indonesia \\ fitria.nurapriani@ubpkarawang.ac.id
}

Abstract-This study aims to determine the effect of service quality an important factor of the service business is the assessment of service quality which is strongly influenced by the perceptions and expectations of each customer. The dimensions of service quality are divided into 5 main dimensions, namely: reliability, responsiveness, assurance, empathy and tangible.This study includes associative research or relationships using quantitative approach. The sample in this study was Telkomsel customers in Karawang Regency who used the MyTelkomsel application. A sample of 100 respondents was determined the sampling snowball method. The research instrument was in the form of a questionnaire. The results of the analysis using SPSS version 16 show that: (1) Reliability influences customer satisfaction (2) Responsiveness influences customer satisfaction (3) Assurance and certainty influences consumer satisfaction (4) Empathy influences customer satisfaction (5) Tangible influences to customer satisfaction.

Keywords: Reliability, Responsiveness, Assurance, Empathy, Tangiblec

Abstrak - Penelitian ini bertujuan untuk mengetahui pengaruh kualitas layanan. Faktor penting dari bisnis jasa adalah penilaian kualitas layanan yang sangat dipengaruhi oleh persepsi dan harapan setiap pelanggan. Dimensi kualitas pelayanan dibagi menjadi 5 dimensi utama yaitu: reliability, responsiveness, assurance, empathy dan tangible Penelitian ini termasuk penelitian asosiatif atau relasi dengan menggunakan pendekatan kuantitatif. Sampel dalam penelitian ini adalah pelanggan Telkomsel di Kabupaten Karawang yang menggunakan aplikasi MyTelkomsel. Sampel sebanyak 100 responden ditentukan dengan metode sampling bola salju. Instrumen penelitian berupa angket. Hasil analisis dengan menggunakan SPSS versi 16 menunjukkan bahwa: (1) Reliabilitas berpengaruh terhadap kepuasan konsumen (2) Responsiveness berpengaruh terhadap kepuasan konsumen (3) Assurance dan kepastian berpengaruh terhadap kepuasan konsumen
(4) Empati berpengaruh terhadap kepuasan konsumen (5) Pengaruh tangible terhadap kepuasan konsumen .

Kata Kunci: Reliabilitas, Responsiveness, Assurance, Empathy, Tangiblec

\section{INTRODUCTION}

The development of technology is now a means that can help activities such as communication, research, and other business transactions. Many mobile phone users and a cell phone are proof that Indonesia is developing telecommunications technology. Telkomsel is an Indonesian communication company whose business process uses information technology specifically the internet. Telkomsel's customer service where to process service problems experienced by customers, customers must go to the Grapari office.

To measure service quality for users, one of which is using the Service Quality Method. This method connects service provider consumers' views regarding the quality of electronic services and measures the level of user satisfaction. Service Quality, measured from the dimensions of Reliability, Assurance, Tangibles, Empathy, and Responsiveness, determine the percentage or group of user satisfaction. Based on the article [1], Telkomsel customers' service is still inadequate because customers have to come to Grapari to incur transport costs, disrupt time, and take a long time to complete are not sufficient. In this case, it attracts researchers to research related to the quality of MyTelkomsel services. A study on service quality on customer satisfaction concludes that acceptable service levels positively affect customer satisfaction. Customer satisfaction is very dependent on the services provided by the company. This certainly supports the goals of Telkomsel.

Based on the article [1], the customer service to Telkomsel is still inadequate because the customer has to come to Grapari to incur transport costs, disrupt time, and take a long time to complete so that it is not practical. In this case, it attracts researchers to be able to research related to the quality of MyTelkomsel services. Research on service quality on 
customer satisfaction concludes that acceptable service levels positively affect customer satisfaction. This was chosen because customer satisfaction is very dependent on the services provided by the company and supports the goals of Telkomsel.

\section{METHOD}

\section{A. Service Quality}

The Service Quality method is a questionnaire used to measure service quality. Developed in the 1980s by Zeithhaml, Parasuraman, and Berry, it used to measure various service qualities. The service Quality method to measure the service quality of each dimension's attributes so that the value of the gap will be obtained, which is the difference between consumer perceptions of the service received and the expected expectation.

Measurement of this method by measuring the quality of the attributes of each dimension, so that the value will be obtained which is the difference between consumer perceptions of the service to be received. However, in general, there is no uniformity of limitations regarding the concept of Service Quality. The service quality model that is most popular and has been widely used as a reference in management and service research is the Service Quality method model developed by Zeithaml et al. In their study [2] of their series of studies on the service sector. This model, also known as the Gap Analysis Model, is closely related to the customer satisfaction model based on the approach confirmed in [3]. This method measures the quality of service quantitatively in a questionnaire containing dimensions of service quality, namely Tangibles, Reliability, Responsiveness, Assurance, and Empathy

\section{B. Service Quality}

The company's quality of service to customers is critical, considering that customers buy its products. This causes companies to compete to provide the best service to their customers. In simple terms, quality can be defined as a defectfree product in research [4]. According to Zeithmal et.al [5], service quality can be defined as "The extent of discrepancy between customer's expectations or desire and their perceptions." Stated that the quality of service received by consumers is stated by the magnitude of the difference between the expectations or desires of consumers and their level of perception.

\section{Service}

Service is an aspect that cannot underestimate in any business competition. Because with customer service, they will evaluate then consider whether they will be loyal to the service provider. So it is not uncommon for business people to maximize their benefits to attract large consumers. Therefore, if you want to attract as many consumers as possible, you must know the meaning of the service itself. The definition of service or service in general, according to Purwadaminta, is to provide everything that other people need. Meanwhile, according to Tjiptono, the definition of service is an activity carried out by a company to customers who have purchased its product.

Service, according to Moenir in [6] service is an activity carried out by a person or group of people based on material factors through certain systems, procedures and methods in order to fulfill the interests of others according to their rights.
Service is essentially a series of activities. Therefore service is a process. As a process, service takes place regularly and continuously, covering all the lives of people in society.

\section{Quality}

According to Lewis and Booms (1983) in [7] and [8], service quality is defined as a measure of how well the level of service provided is following customer/user expectations. Based on another definition, service quality can realize by fulfilling customers' needs and desires and delivery to match the customer. Service quality can be identified by comparing consumers' perceptions of the service they expect or want against the service attributes of a company.

\section{E. Customer Satisfaction}

According to Kotler, customer satisfaction is the level of a person's feelings after comparing the performance or perceived results compared with expectations. Service quality and customer satisfaction are essential elements that must be accounted for to improve company goals [9].

This research uses descriptive and causal analysis with a quantitative approach. According to Riduwan [10], a descriptive study is directed to solve problems by describing or describing the research results. Causal research, according to [11] is a type of research where there is a causal relationship between the independent variable (the variable that affects) and the dependent (the variable that is affected) [13].

This study uses a quantitative approach, namely research by analyzing data using numbers. This research is field research, and this is because in obtaining data from direct observations to users using a questionnaire method. The sources used are the actors involved in customer satisfaction of Telkomsel services. The questionnaire is used to explore related customer satisfaction, actors, and documents involved in customer satisfaction. The procedures carried out in this study are as follows:

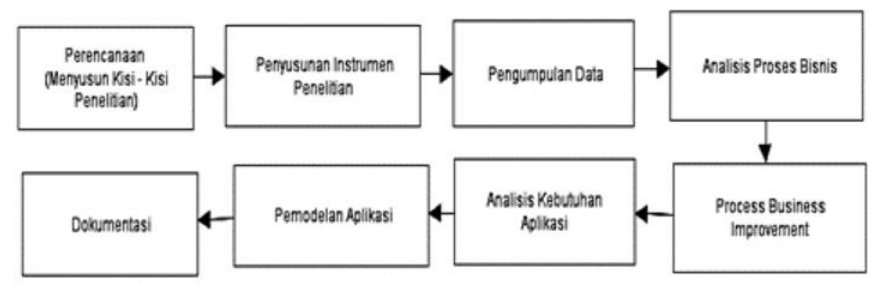

Fig. 1 Research Methods

1. Research planning: at this stage, the researcher prepares a research grid where the data or information extracted to describe data sources, data collection techniques, and questions to be asked to the data source.

2. Compilation of Research Instruments: at this stage, the researcher arranges research instruments based on the grid arranged. After the instrument.

3. The instrument test was arranged for several respondents, then tested the validity and reliability. After the instrument was deemed valid and reliable, the instrument could be distributed to the respondents who had been appointed.

4. Data Collection: At this stage, the researcher collects data based on the grid that has been made and with the instrument that has been prepared. 
5. Data processing: At this stage, the researcher tested the validity and reliability of the data collected. Then the data is processed using descriptive statistics, and then the hypothesis is tested.

6. Preparation of reports: At this stage, the researcher prepares a report representing data interpretation and discussion of this research.

\section{RESULT AND DISCUSSION}

A. Characteristics of Research Subjects

This description provides an overview of the research subject, where this study describes the respondents' characteristics as research subjects. The topics referred to in this study are customers who use Telkomsel in Karawang. In this study, Telkomsel users were selected as a population of respondents because they already know Telkomsel, which can help provide accountable data. Taking respondents as samples in this study, several customers in the Karawang area are 100 respondents.

\section{B. Data Acquisition}

To obtain data about the factors that affect customer satisfaction of MyTelkomsel, Karawang Regency, questionnaires were distributed to MyTelkomsel users. The questionnaires were distributed to 100 people and distributed to customers in Karawang Regency. This happened because did the filling online, did this because the covid 19 outbreak researchers could not distribute questionnaires directly in distributing questionnaires, researchers gave directions to respondents to fill out questionnaires.

\section{Validity Test}

According to Sugiyono [12] "Validity is valid means that can use the instrument to measure what should be measured." Based on the validity test of the research instrument using the correlation matrix of the SPSS version 16 calculation results and the rtabel table, where the test results show that the instrument is said to be valid if rcount> rtabel, where if we look at the $r$ table with the number of respondents (N) 100 then the $r$ table is 0.195 .

Table 1 Validity Test Result

\begin{tabular}{cccc}
\hline Item & rhasil & Rtabel & Ket \\
\hline R1 & 0,770 & 0,195 & Valid \\
\hline R2 & 0,783 & 0,195 & Valid \\
\hline R3 & 0,746 & 0,195 & Valid \\
\hline A1 & 0,585 & 0,195 & Valid \\
\hline A2 & 0,640 & 0,195 & Valid \\
\hline A3 & 0,633 & 0,195 & Valid \\
\hline A4 & 0,629 & 0,195 & Valid \\
\hline A5 & 0,741 & 0,195 & Valid \\
\hline A6 & 0,676 & 0,195 & Valid \\
\hline T1 & 0,616 & 0,195 & Valid \\
\hline T2 & 0,787 & 0,195 & Valid \\
\hline T3 & 0,790 & 0,195 & Valid \\
\hline T4 & 0,653 & 0,195 & Valid \\
\hline E1 & 0,812 & 0,195 & Valid \\
\hline E2 & 0,741 & 0,195 & Valid \\
\hline E3 & 0,806 & 0,195 & Valid \\
\hline
\end{tabular}

\begin{tabular}{llll}
\hline E4 & 0,722 & 0,195 & Valid \\
\hline S1 & 0,710 & 0,195 & Valid \\
\hline S2 & 0,782 & 0,195 & Valid \\
\hline S3 & 0,808 & 0,195 & Valid \\
\hline S4 & 0,781 & 0,195 & Valid \\
\hline
\end{tabular}

From the results of the acquisition of the above variables (Reliability, Assurance, Tangible, Emphaty, Responsiveness) all of them produce a value (rHitung)> than (rTabel) of 0.195 . So it can be concluded that all instruments in this study are said to be valid.

\section{Reliability Test}

Table 2. Reliability Test

\begin{tabular}{cccc}
\hline Item & Alpha & rtabel & Keterangan \\
\hline $\mathrm{R}$ & 0,645 & 0,6 & Reliabel \\
\hline $\mathrm{A}$ & 0,673 & 0,6 & Reliabel \\
\hline $\mathrm{T}$ & 0,670 & 0,6 & Reliabel \\
\hline $\mathrm{E}$ & 0,772 & 0,6 & Reliabel \\
\hline $\mathrm{S}$ & 0,772 & 0,6 & Reliabel \\
\hline
\end{tabular}

From the results of the reliability test, all the results of all variables (Reliability, Assurance, Tangible, Emphaty, Responsiveness) resulted in all cronbach's alpha values> 0.6. So it can be concluded that all the instruments in this study are reliable.

\section{A. Analisis Service Quality}

Analysis of service quality with the Service Quality (Servqual) model. In this study, the dimensions related to service quality are reliability, assurance and assurance, tangibles, Empathy, and responsiveness. The five dimensions have attributes in each dimension and In this study, there were 21 statements submitted to MyTelkomsel users, Karawang Regency. All data attributes to respondents will be tested using validity and reliability tests to show whether the data is valid and reliable or not. Based on the validity and reliability tests results, stated that all data from the respondents were valid. So can used in Servqual calculations.

Servqual analysis was carried out by looking at the gaps between the expected services and the services received by users. From the results of the study of service quality, it can conclude that the level of service quality for each dimension (reliability, assurance, tangibles, responsiveness) still needs to be improved. Whereas for variables so that users have well felt the Empathy on the MyTelkomsel application.

The Service Quality method is a questionnaire used to measure service quality. Developed in the 1980 s by Zeithhaml, Parasuraman, and Berry, it has been used to measure a variety of service qualities. The service Quality method is a method used

\section{B. Recommendations}

The service quality method is a crucial aspect in assessing the quality of service results from research obtained from the findings that have produced, so the authors provide recommendations such as the following:

1. Based on the results of research that has been conducted by the author, the respondent's assessment of 
MyTelkomsel service quality that gets the lowest rating is the Tangible indicator, which received a low rating from Telkomsel users. Therefore, the recommendation given is that the company optimizes the services provided so that it can touch the heart of Telkomsel users, besides improving Customer Service response in handling customer complaints and updating MyTelkomsel features very attractive to users.

2. Service Quality in Reliability, Assurance, Empathy, Responsiveness (Responsiveness), gets good scores from MyTelkomsel users. Overall Service Quality proved in the assessment of service quality, and sincere service is a factor that influences users to stay loyal to use Telkomsel services. In this case, the author recommends that the company continue to maintain and improve the quality of service and exclusive features that are easy to understand.

The research results on the level of customer satisfaction Telkomsel regarding customer satisfaction with MyTelkomsel users, Karawang Regency. Based on the data obtained from the questionnaire that has been collected and has been statistically analyzed, it is found that the level of customer satisfaction Telkomsel is quite satisfying from the questionnaire statement on Telkomsel customers very satisfying.

Telkomsel's customer satisfaction level, based on data obtained from collected questionnaires and has been statistically analyzed, then seen from the questionnaire and in the table shows that customers are quite satisfied with the MyTelkomsel application. From the respondent's assessment of customer satisfaction, namely in the variable reliability, there are three statement items in the statement the most exceptional item. Namely, Telkomsel Provides Promised Service Immediately so that the highest score is obtained, namely 397 , the three statement items have a total of 1,173 .

Furthermore, from the respondent's assessment of customer satisfaction, namely in the Assurance and Assurance variable, there are six items of the highest statement score, namely in the customer-friendly Telkomsel service item. Intangible variables, the most respondents 'responses were Telkomsel's features that were easy to understand, and on the Empathy variable, most respondents' answers were Telkomsel who gave attention to complaints from customers. Also, most respondents' responses to Telkomsel's Responsiveness variable provide the information needed to customers. All the respondents' responses indicate that MyTelkomsel users in Karawang Regency are satisfied with Telkomsel's services.

\section{CONCLUSION}

Based on final study, the level of satisfaction of the research results shows very satisfyingly, namely in Customer Service. In this case, the Telkomsel company should continue to provide maximum and increasing service quality so that consumers remain loyal to use the MyTelkomsel application. There is a positive relationship between service quality variables and company image, where the better the quality of service performed by Customer Service, the more positive the company image is. So it can be concluded, the notion that is formed can be determined by the quality of service (Customer Service) to customers.

From the correlation between customer service quality variables, it is known that the highest value is in the dimension of assurance and assurance, while the lowest value is in the tangible dimension. This shows that the assurance capabilities related to the quality of Telkomsel and Customer Service services have a strong relationship to improve the company's image.

\section{REFERENCES}

[1] J. Rewah, "Pengaruh Kualitas Layanan Online Terhadap Kepuasan Pelanggan Telkomsel Manado," Cogito Smart J., Vol. 2, No. 2, P. 250, 2016, Doi: 10.31154/Cogito.V2i2.34.250-263.

[2] M. Jazuli And D. Samanhudi, "Analisis Kualitas Pelayanan Dengan Servqual Dan Importance Performance Analysis Di Pt . Xyz," Vol. 01, No. 01, Pp. 67-75, 2020.

[3] A. Suryadi, "Dengan Metode Servqual Dan Triz ( Studi Kasus Pada “Cafe Xyz )," Vol. 01, No. 01, Pp. 76-86, 2020.

[4] S. Wahyuni And J. Pardamean, "Pengaruh Iklan , Harga Dan Kualitas Layanan Terhadap Keputusan Pembelian Kartu Simpati," Vol. 3, No. 1, Pp. 13-30, 2016.

[5] Destria Justitie, “3) 1, 2, 3)," Anal. Pengaruh Kualitas Produk, Cita Rasa, Dan Harga Terhadap Loyal. Pelangg. Waffelio Franch. Di Surakarta, No. 3, Pp. 243-253, 2010.

[6] S. Rusnani, "Persepsi Masyarakat Tentang Pelayanan Publik Di Kantor Kelurahan Handil Bakti Kecamatan Palaran Kota Samarinda," Ejournal Adm. Negara, Vol. 1, No. 2, Pp. 365-379, 2013.

[7] N. R. Pioh, “Issn : 2337 - 5736," Vol. 4, No. 4, Pp. 110,2020

[8] V. M. Ardianto, "Strategi Meningkatkan Loyalitas Melalui Kepuasan Pelanggan (Studi Produk Kartu Seluler Prabayar Victor Marindra Ardianto Sekolah Tinggi Ilmu Ekonomi Gentiaras Lampung," Vol. Viii, Pp. 164-174, 2016.

[9] Selvi, “Jurnal Administrasi Bisnis (Jab) | Vol. 6 No. $2 \quad$ Desember 2013 | Administrasibisnis.Studentjournal.Ub.Ac.Id 1," Vol. 6, No. 2, Pp. 1-9, 2013.

[10] A. Wijayanto, "March 2020 Revised: 20," Eff. Organ. Cult. Motiv. Job Satosfication Empl. Perform., Vol. 1, No. 4, Pp. 492-502, 2020, Doi: 10.31933/Dijdbm.

[11] U. Telkom, "Consumer Purchase Intention: The Effect Of Green Brand And Green Knowledge On Indonesian Nestle Company Minat Beli Konsumen: Dampak Green Brand Dan Green Knowledge Pada Perusahaan Nestle Indonesia,” Vol. Iii, No. 1, Pp. 39- 
50, 2019.

[12] K. Ratnasari, A. Kurniawan, And A. Suangga, "Effect Of E-Filing Socialization On Tax Compliance With E-Filing Understanding As An Intervening Variable ( Case Study Of Individual Taxpayers Of Employees Registered On Kpp Pratama Purwakarta )," Pp. 1-11, 2019.

[13] B. P. April Lia Hananto, "Rancang Bangun Aplikasi Informasi Harga Produk," TechnoXplore, vol. 2, no.1, pp. 10-20, 2017. 